\title{
FATORES DE VIRULÊNCIADE LINHAGENS DE Escherichia coli ISOLADAS DE DEJETOS RESIDENCIAIS
}

\author{
Gisele Aparecida Andrade da Sé ${ }^{1}$; Elinalva Maciel Paulo ${ }^{2}$; Claudio Roberto \\ Nobrega Amorim ${ }^{3}$ \\ 1. Bolsista FAPESB, Graduando em Medicina, Universidade Estadual de Feira de Santana, e-mail: \\ giseleandrade_fsa@hotmail.com \\ 2. Elinalva Maciel Paulo, Departamento de Ciências Biológicas, Universidade Estadual de Feira de Santana, e-mail: \\ elinalvamaciel@yahoo.com.br \\ 3. Claudio Roberto Nobrega Amorim, Departamento de Ciências Biológicas, Universidade Estadual de Feira de \\ Santana, e-mail: $\underline{\text { amorim@uefs.br }}$
}

PALAVRAS-CHAVE: Fatores virulência, E. coli, dejetos residenciais.

\section{INTRODUÇÃOO}

Os dejetos residenciais são compostos por coliformes fecais. Este grupo é constituído por bactérias do gênero Citrobacter, Escherichia e Klebsiella. São bacilos aeróbicos ou anaeróbios facultativos, Gram negativos, não formadores de esporos, oxidase-negativos, que fermentam lactose com produção de ácido, gás a $35,0 \pm 0.5^{\circ} \mathrm{C}$ em $24-48$ horas. (DE MELO, 2006)

A contaminação da água por coliformes fecais possibilita a ocorrência das Doenças Transmitidas por Água e Alimentos (DTAs); que têm como principais sintomas a diarreia, mal-estar geral, dor abdominal, náusea, vômito e febre; podendo em alguns casos ocorrer desidratação. Os agentes causadores da DTA bacteriana são o Bacillus cereus, Clostridium perfringens, Salmonella, Shigella, Staphylococcus aureus, Escherichia coli patogênica e outras. (COVISA, 2011)

A E. coli trata-se de bacilo, Gram negativo, anaeróbio facultativo, com cepas saprofíticas e patogênicas. As cepas patogênicas possuem diferentes fatores de virulência, como proteínas de adesão, de invasão e proteínas tóxicas que irão variar o espectro de manifestações clínicas. Assim, a E. coli patogênica pode ser classificada em enteropatogênica (EPEC), enterohemorrágica (EHEC), enterotoxigênica (ETEC), enteroagregativa (EAEC), enteroinvasivas (EIEC) e que aderem difusamente (DAEC).

A EPEC apresenta como fatores de virulência: A) Fímbria BFP (bundle-formingpili), responsável pela aderência à célula epitelial e formação de micro colônias, sendo oriunda de um grande plasmídio EAF (EPEC AdherenceFactor). B) Proteína intimina, codificada pelo gene eae. C) Aparelho de secrecão do tipo III.Os genes eae e o esp estão localizados na região LEE (LocusofEnterocyteEffacement).

$\mathrm{Na}$ ETECos fatores de virulência são enterotoxinas termolábeis LT I e LT II codificada pelos genes eltI e eltII; e as termoestáveis STa e STb - codificadas pelos genes stlA e stlB, ambos os genes são localizados em plasmídeos. Há também os Fatores de Colonização Antigênicos (CFA I a CFA IV).

As EHEC têm como fator principal de virulência a toxina Shiga (Stx) ou toxina "Shigalike" (SLT), denominada dessa forma devido à similaridade com a toxina da Shigella dysenteriae.

Sobre os fatores de virulência das EAEC, encontramos a fímbrias de aderência agregativa (AAFs); protease mucolitica - PIC (proteininvolved in intestinal colonization); Shigella enterotoxin1 (SHEt1); enterotoxinas EAST-1, similar à STa da ETEC; além da toxina PET (Plasmid-encodedtoxin), responsável por alterações no citoesqueleto celular.

A EIEC também possui o sistema de secreção tipo III, serina-protease (SepA), sistema de aquisição de ferro e outras proteases. 
A DAEC possui uma adesina chamada F1845, codificada por DNA de plasmídeos ou de cromossomos.

Devido ao grande potencial de contaminação da água por dejetos residenciais, que podem levar ao surgimento das DTAs e sendo a Escherichia coli um dos agentes etiológicos dessa morbidade; justifica-se um estudo sobre os diferentes fatores de virulência dos diversos sorotipos desse micro-organismo. Para melhor entender essa patologia de alta incidência e seus diferentes espectros sintomatológicos.

\section{MATERIAL E MÉTODOS}

Trabalho realizado durante os meses de agosto de 2016 até agosto de 2017, em Feira de Santana.

\section{Coleta da amostra}

As amostras seriam coletadas em diferentes Condomínios de Feira de Santana que possuem central de resíduos de origem residencial, sendo esses distribuídos em tubos contendo o meio de Cary-Blair (LEW et al, 1990) e imediatamente transportadas para o LAMASP, onde seriam realizados os isolamentos. Mas não houve liberação pelos responsáveis, assim as bactérias foram ativadas a partir da bacterioteca do LAMASP.

\section{Isolamento de Escherichia coli.}

As bactérias foram inoculadas em meio BHI e incubadas a $35^{\circ} \mathrm{C}$ durante $24-48 \mathrm{hs}$; sendo depois inoculadas no caldo EC contendo tubo de Durhan, para incubação a $45^{\circ} \mathrm{C}$ por 24hs em banho-maria. As culturas que apresentaram crescimento com presença de gás no tubo de Durhan foram semeadas no Agar Eosina-Azul de Metileno (EMB). Sendo o EMB utilizado para isolamento primário de todas as espécies de bacilos entéricos Gramnegativos. As placas foram incubadas a $35^{\circ} \mathrm{C}$ durante $24 \mathrm{~h}$ a $48 \mathrm{hs}$, e foram selecionadas colônias suspeitas de E. coli (colônias verdes metálicas ou enegrecidas) para a identificação bioquímica.

As provas bioquímicas foram realizadas com colônias suspeitas de cada amostra e consistem em: Utilização dos carboidratos (glicose, sacarose e lactose), produção de indol, prova do vermelho metila, prova de Voges-Proskauer, utilização do citrato, produção de uréase, descarboxilação da lisina e arginina, produção de fenilalanina desaminase, produção de sulfeto de hidrogênio, prova da motilidade. (KONEMAN, 2001)

\section{Extração de DNA bacteriano}

Utilizando o método de Boom et al (1990) com algumas modificações. Os reagentes utilizados nesse método de extração serão compostos por: (MELO)

- Tampão de Lise

o Isotiocianato de guanidina $-120 \mathrm{~g}$

- Triton $100 \mathrm{X}-1 \mathrm{~mL}$

○ EDTA $0.5 \mathrm{M}(\mathrm{pH} 8.0)-8,8 \mathrm{~mL}$

○ Tris- $\mathrm{HCl0.1} \mathrm{M} \mathrm{(pH} \mathrm{6.4)} \mathrm{-} \mathrm{111,2mL}$

- Tampão de Lavagem

o Isotiocianato de guanidina $-120 \mathrm{~g}$

○ Tris-HCl0.1 M (pH6,4) - 100mL

- Solução Carreadora

o Sílica $-1 \mathrm{~g}$

- Água destilada - 5mL

○ $\mathrm{HCl} 37 \%-50 \mu \mathrm{l}$

- Tampão de Eluição 
○ 10 mM Tris- $\mathrm{HCl}(\mathrm{pH} 7.5)$

○ $1 \mathrm{mM}$ EDTA

\section{Protocolo de extração}

A colônia selecionada foi suspensa em $200 \mu$ de água ultrapura auto clavada em micro tubo de $1.5 \mu \mathrm{l}$, adicionando-se $1 \mathrm{~mL}$ de Tampão de Lise e $40 \mu 1$ de solução carreadora. Em seguida, foram agitadas por 30 segundos e deixadaspara incubar por 10 minutos à temperatura ambiente. Centrifugando a $12000 \mathrm{G}$, por 90 segundos, foi feita remoção do sobrenadante sem tocar no pellet e serão adicionadas $0.5 \mathrm{~mL}$ de Tampão de Lavagem, agitando por 15 segundos em vórtex e novamente centrifugando a $12000 \mathrm{G}$, por 90 segundos. Foi descartado o sobrenadante e repetiçãodo procedimento de lavagem mais uma vez. Descartando o sobrenadante novamente e adicionando $0.5 \mathrm{~mL}$ de Etanol (70\%) agitando por 15 segundos em vórtex e centrifugando a $12000 G$ por 90 segundos. Repetido o procedimento mais uma vez. Descartado o sobrenadante e adicionado $0.5 \mathrm{~mL}$ de Acetona e agitando por 15 segundos em vórtex, centrifugando, em seguida, a 12000 $G$ por 90 segundos. O sobrenadante foi descartado e deixado para secar o pellet. Adicionou-se $150 \mu \mathrm{l}$ de Tampão de Eluição seguindo de agitação em vortex por 60 segundos. Incubando a $56^{\circ} \mathrm{C}$ por 10 minutos em banho. Feita agitação em vórtex por 60 segundos e centrifugação a $12000 G$ por 5 minutos. Foi removido o sobrenadante contendo o DNA para novos tubos, posteriormente foi feito armazenamento do material extraído a $-20^{\circ} \mathrm{C}$.

\section{Pesquisa dos genes de virulência pela reação em cadeia de polimerase}

Depois da extração do DNA, as amostras seriam submetidas à reação de PCR utilizando iniciadores específicos para os genes stx1, stx2, eltI e eae que codificam para Toxina Shiga ou shiga-like, toxina LT e intimina, respectivamente. As reações de PCR seriam realizadas utilizando o DNA das linhagens de referência EPEC ATCC 0127a, EHEC ATCC 933, ETEC UNICAMP como controles positivos e E. coli ATCC 25723 como controle negativo.

Todas as reações de PCR seriam realizadas para um volume final de $30 \mu 1$, e os reagentes utilizados seriam: água deionizada: 17,1 $\mu \mathrm{l}$; PCR buffer 10x: $2 \mu \mathrm{l}$; dNTP 10mM: $0,6 \mu \mathrm{l}$; Iniciador 1: $1,5 \mu \mathrm{l}$; Iniciador 2: $1,5 \mu \mathrm{l}$; $50 \mathrm{mM} \mathrm{MgCl2:} 2 \mu \mathrm{l}$; Taq polimerase

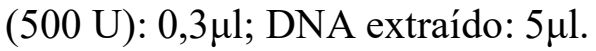

Todas as reações seriam submetidas a 30 ciclos que tiveram as seguintes etapas:

1- Desnaturação Inicial: $94^{\circ} \mathrm{C}$ por 5 minutos

2- Desnaturação: $92^{\circ} \mathrm{C}$ por 1 minuto

3- Anelamento: $55^{\circ} \mathrm{C}$ (EHEC) $/ 50^{\circ} \mathrm{C}$ (ETEC) / $63^{\circ} \mathrm{C}$ (EPEC) por 30 segundos

4- Extensão: $72^{\circ} \mathrm{C}$ por 30 segundos

5- Fechamento: $73^{\circ} \mathrm{C}$ por 10 minutos

\section{RESULTADOS EDISCUSSÃO}

Dentre os resultados esperados estavam a caracterização de sorotipos de Escherichia coli isoladas de dejetos residências, para compor dados epidemiológicos em Feira de Santana; além da identificação dos fatores de virulência dos sorotipos encontrados e a publicação de artigos sobre o tema. Os resultados alcançados foram o isolamento da bactéria $E$. coli e a extração de material genético, contudo devido a indisponibilidade dos materiais para PCR a identificação]ao dos fatores de virulência não foi realizada. 


\section{CONSIDERAÇÕES FINAIS}

Como dito as etapas inicias do trabalho foram realizada; como a coleta de amostra, o isolamento e a identificação das linhagens de E. coli. Todavia a identificação dos fatores de virulência não foi possível, já que a sua realização precisa da reação em cadeia de polimerase (PCR) e os "primers" comprados demoraram para chegar e, quando chegaram, estavam errados. Novos "primers" foram solicitados em substituição, mas ainda não chegaram.

\section{REFERÊNCIAS}

BARBOSA, M. M. C. Identificação sorológica e perfil de susceptibilidade a antimicrobianos em amostras de Escherichia coli isoladas de peixes e água de pesque-pagues. 2010. Dissertação apresentada a Faculdade de Ciências Agrarias e Veterinárias - UNESP, Campus de Jaboticaba, 67p. Jaboticabal, SP. BR, 2010.

BERTÃ O, A. M. S.; SARIDAKIS, H. O. Escherichia coli produtora de toxina shiga (STEC): principais fatores de virulência e dados epidemiológicos. Semina: Ciências Biológicas e da Saúde. Londrina, v.28, n.2,p.81-92, jul/dez, 2007.

DE MELO, S. K. Caracterização de fatores de virulência em amostras de Escherichia coli isoladas de lagoas do Parque Estadual do Rio Doce-MG. Minas Gerais, 2006.

GUASTALLI, E. A. L. Estudo dos fatores de virulência, sorogrupos, patogenicidade e susceptibilidade antimicrobiana das cepas de Escherichia coli isoladas de pintainhas de reposição de postura. Jaboticabal, 2010.

KENNY, B.; DEVINNEY, R.; STEIN, M.; REINSCHEID.; FREY, E.A.; FINLAY, B.Enteropathogenic E. coli (EPEC) Transfers Its receptor for intimate adherence into mammalian cells. Cell, v.91, 511-520, Novembro, 1997.

KONEMAN, E. W., AlLEN, S. D., JANDA, W. M., SCHRECKENBERGER, P. C., WINN, W. C. Diagnóstico Microbiológico. 6 6. Edição.Editora Guanabara Koogan. 2008.

LEW, J.F.; LEBARON.C.W.; GLASS,R.I.; TOROK,T.;GRIFFIN,P.M.; WELLS,J.G.; JURANEK.D.D.; WAHLQUIST,S.P. Recommendations for Collection of Laboratory Specimens Associated with Outbreaks of Gastroenteritis. MMWR, v39, n. RR-14, p.1- 13, 1990.

NETO; U.F.; SCALESKY, I. C.A.F. The gut at war: the consequences of enteropathogenic Escherichia coli infection as a factor of diarrhea and malnutrition. Revista Paulista de Medicina:118 (1): 21-9. São Paulo, 2000.

PAULO, E. M. 2010. Produção de exopolissacarídeos (EPS) por bactérias láticas visando microencapsulação de Lactobacillus acidophilus La-5 pelo processo de Spray drying. 2010. Tese 212f. (Doutorado em Biotecnologia), Departamento de Ciências Biológicas, Universidade Estadual de Feira de Santana, Feira de Santana.

SALDENBERG, A. B. S. Detecção de fatores de virulência de Escherichia coli isoladas de psitacídeos com diferentes manifestações clínicas. São Paulo, 2008.

STELLA, A. E. Fatores de virulência em isolados de Escherichia coli provenientes de amostras de água, leite e fezes bovinos leiteiros da região de Ribeirão Preto-SP, Brasil. Jaboticabal-SP, 2009.

VIERA, M.A.M. Ilhas de patogenicidade. O mundo da saúde: 33(4): 406-414. São Paulo, 2009 